\title{
ISSUES OF ESTIMATING AND COMPENSATING FOR LOSSES TO INDIGENOUS PEOPLES IN THE CONDITIONS OF INDUSTRIAL DEVELOPMENT OF THE ARCTIC
}

\author{
Burtseva E. I. \\ M. K. Ammosov North-Eastern Federal University (Yakutsk, Russian Federation) \\ Potravny I. M. \\ Plekhanov Russian University of Economics (Moscow, Russian Federation) \\ Gassiy V. V. \\ Kuban State University (Krasnodar, Russian Federation) \\ Sleptsov A. N., Velichenko V. V. \\ M. K. Ammosov North-Eastern Federal University (Yakutsk, Russian Federation)
}

The article was received on November 8, 2018

\begin{abstract}
The article considers the results of a study on the development of the assessment and compensation of losses caused to indigenous minorities of the North in the implementation of industrial development projects in the Arctic. Domestic and foreign experience, economic mechanisms of coordination and harmonization of multivector and conflicting interests in the process of industrial development of the traditional nature management territories are analyzed. The developed recommendations will enable, on the one hand, to compensate the losses incurred by the representatives of the indigenous minorities of the North, and on the other, to involve representatives of the indigenous minorities of the North in the process of environmental management and socio-economic development of the Arctic territories, taking into account the preservation of their original habitat.
\end{abstract}

Keywords: indigenous minorities of the North, investment projects, traditional nature management, economic mechanism, damage, the Arctic.

The article was prepared with the financial support of a grant of the Russian Foundation for Basic Research (RFBR) "Development of a methodology for assessing damage to indigenous minorities of the North in industrial development of the traditional nature management territories", project №17-02-00214.

\section{References}

1. Potravnyi I. M., Motorina M. A. Razvitie opornykh zon v Rossiiskoi Arktike na osnove proektnogo podkhoda. [The Development of reference areas in the Russian Arctic on the basis of the design approach]. Gorizonty ekonomiki, 2017, no. 6 (39), pp. 31-37. (In Russian). 2. Novoselov A., Potravny I., Novoselova I., Gassiy V. Selection of priority investment projects for the development of the Russian Arctic. Polar Science, 2017, Vol. 14, Dec., pp. 68-77.

3. Novoselov A., Potrannii I., Novoselova l., Gassiy V. Conflicts Management in Natural Resources Use and Environment Protection on the Regional Level. J. of Environmental Management and Tourism: ASERS Publ., 2016, vol. 7, no. 3 (15), pp. 407-415.

4. Sleptsov A. N. Voprosy normativnogo zakrepleniya etnologicheskoi ekspertizy $v$ mestakh traditsionnogo prozhivaniya i khozyaistvennoi deyatel'nosti korennykh malochislennykh narodov Severa na primere Yakutii. [Issues of Statutory Establishment of Ethnologic Examination in Places of Traditional Residence and Business Activity of Indigenous Small-Numbered Peoples of the North on Example of Yakutia]. Yurist, 2017, no. 19, pp. 42-46. (In Russian).
5. Gladkov A. A., Nosov S. I., Sapozhnikov P. M. Printsipy opredeleniya ubytkov traditsionnoi khozyaistvennoi deyatel'nosti $v$ zone severnogo olenevodstva. [Principles of determination of losses of traditional economic activity in the zone of Northern reindeer breeding]. Sovremennye problemy upravleniya proektami v investitsionno-stroitel'noi sfere i prirodopol'zovanii: Materialy VIII mezhdunarodnoi nauchno-prakticheskoi konferentsii. Moscow, REU im. G. V. Plekhanova, 2018, pp. 95-101. (In Russian).

6. Ignat'eva M. N., Loginov V. G., Litvinova A. A., Morozova L. M., Ektova S. N. Ekonomicheskaya otsenka vreda, prichinyaemogo Arkticheskim ekosistemam pri osvoenii neftegazovykh resursov. [The economic assessment of harm to the arctic ecosystems at the development of oil and gas resources]. Ekonomika regiona, 2014, no. 1 (37), pp. 102-111. DOI: 10.17059/2014-1-9. (In Russian).

7. Loginov V. G., Ignat'eva M. N., Balashenko V. V. Vred, prichinennyi resursam traditsionnogo prirodopol'zovaniya, i ego ekonomicheskaya otsenka. [Harm to the Resources of Traditional Nature 
Management and Its Economic Evaluation]. Ekonomika regiona, 2017, vol. 13, no. 2, pp. 396-409. DOI: 10.17059/2017-2-6. (In Russian).

8. Nosov S. I., Bondarev B. E. Opredelenie ubytkov zemlepol'zovatelei $v$ Rossiiskoi Arktike pri dobyche poleznykh iskopaemykh. [Definition of losses of land users in the Russian Arctic during mining]. Korennye narody Sibiri: istoriya, traditsii i sovremennost': Materialy regional'noi nauchno-prakticheskoi konferentsii. Sost. O. P. Domozhakova. Abakan, Khakas. kn. izd-vo, 2018, pp. 144-151. (In Russian).

9. Burtseva E. I. Kompensatsiya ubytkov, prichinennykh ob"edineniyam korennykh malochislennykh narodov $v$ usloviyakh promyshlennogo osvoeniya territorii. [Compensation of losses caused to associations of indigenous peoples in terms of industrial development of the area]. Ekonomika prirodopol'zovaniya, 2018, no. 2, pp. 23-38. (In Russian).

10. Samsonova I. V., Pavlova M. B. Rossiiskii i mezhdunarodnyi opyt vozmeshcheniya ushcherba korennym malochislennym narodam pri resursnom osvoenii territorii. [The Russian and international experience of compensation of damage to indigenous ethnic groups at resource development of territories]. Arktika. XXI vek. Gumanitar. nauki, 2017, no. 3 (13), pp. 52-61. (In Russian).

11. Sleptsov A. N. Etnologicheskaya ekspertiza v mestakh traditsionnogo prozhivaniya i traditsionnoi khozyaistvennoi deyatel'nosti narodov Severa: regional'nyi opyt pravovogo regulirovaniya i pravoprimenitel'noi praktiki. [Ethnological expertise at the places of traditional habitat and traditional economic activity of the peoples of the North: regional experience of legal regulation and practice]. Evraz. yurid. zhurn, 2013, no. 12 (67), pp. 71-75. (In Russian).

12. Potravnyi I. M., Gassii V. V., Tambovtseva T. T. Etnologicheskaya ekspertiza kak instrument soglasovaniya interesov tselevykh grupp $v$ sfere traditsionnogo prirodopol'zovaniya. [Ethnological examination as a tool for coordination of interests of target groups in the field of traditional nature use]. Ekonomika prirodopol'zovaniya, 2016, no. 3, pp. 80-92. (In Russian).

13. Potravnyi I. M., Gassii V. V., Chernogradskii V. N., Postnikov A. V. Sotsial'naya otvetstvennost' kompanii-nedropol'zovatelei na territorii traditsionnogo prirodopol'zovaniya kak osnova partnerstva vlasti, biznesa i korennykh malochislennykh narodov. [Social responsibility of mining companies in the territory of traditional nature management as a basis for partnership between the government, business and indigenous peoples of the North]. Arktika: ekologiya i ekonomika, 2016, no. 2 (22), pp. 56-63. (In Russian).

14. Sleptsov A. N. Gosudarstvennaya etnologicheskaya ekspertiza Respubliki Sakha (Yakutiya). [The State ethnological examination in the Republic of Sakha (Yakutia)]. Arktika XXI vek. Gumanitar. nauki, 2015, no. 1 (4), pp. 15-24. (In Russian).

15. Burtseva E. I., Kychkin V. R., Fedorov S. P., Burtsev I. S., Barashkov N. A. Problema kompensatsii ekologicheskogo i sotsial'nogo ushcherba v Yakutii, vyzvannogo dobychei almazov. [The problem of compensation for environmental and social damage in Yakutia caused by diamond mining]. Region. ekonomika: teoriya i praktika, 2009, no. 40 (133), pp. 8-17. (In Russian).

\section{Information about the authors}

Burtseva Evdokia Innokentievna, Doctor of Geographical Sciences, Professor, M. K. Ammosov North-Eastern

Federal University (58, Belinsky st., Yakutsk, Russia, 677000), e-mail: burtseva1999@mail.ru.

Potravny Ivan Mikhaylovich, Doctor of Economics, Professor, Plekhanov Russian University of Economics (36, Stremyanny per., Moscow, Russia, 117997), e-mail: ecoaudit@bk.ru.

Gassiy Voletta Valer'evna, Doctor of Economics, Professor, Kuban State University (149, Stavropolskaya st., Krasnodar, Russia, 350040), e-mail: vgassiy@mail.ru.

Sleptsov Anatoly Nikolaevich, PhD, Head of Department, M. K. Ammosov North-Eastern Federal University (58,

Belinsky st., Yakutsk, Russia, 677000), e-mail: uyandi@mail.ru.

Velichenko Valery Vladimirovich, PhD, Leading researcher, Institute of applied ecology, M. K. Ammosov NorthEast Federal University (58, Belinsky st., Yakutsk, Russia, 677000), e-mail: ipes-08@mail.ru.

\section{Bibliographic description}

Burtseva E. I., Potravny I. M., Gassiy V. V., Sleptsov A. N., Velichenko V. V. Issues of estimating and compensating for losses to indigenous peoples in the conditions of industrial development of the Arctic. Arctic: Ecology and Economy, 2019, no. 1 (33), pp. 34-49. DOI: 10.25283/2223-4594-2019-1-34-49. (In Russian). 


\title{
ВОПРОСЫ ОЦЕНКИ И КОМПЕНСАЦИИ УБЫТКОВ КОРЕННЫМ МАЛОЧИСЛЕННЫМ НАРОДАМ В УСЛОВИЯХ ПРОМЫШЛЕННОГО ОСВОЕНИЯ АРКТИКИ
}

Е. И. Бурцева

ФГАОУ ВО «Северо-Восточный федеральный университет им. М. К. Аммосова»

(Якутск, Российская Федерация)

\section{И. М. Потравный}

ФГБОУ ВО «Российский экономический университет им. Г. В. Плеханова»

(Москва, Российская Федерация)

\section{В. В. Гассий}

ФГБОУ ВО «Кубанский государственный университет» (Краснодар, Российская Федерация)

\author{
А. Н. Слепцов, В. В. Величенко \\ ФГАОУ ВО «Северо-Восточный федеральный университет им. М. К. Аммосова» \\ (Якутск, Российская Федерация)
}

Статья поступила в редакцию 8 ноября 2018 г.

\begin{abstract}
Рассматриваются результаты исследования по проблеме развития оценки и компенсации убытков, причиненных коренным малочисленным народам Севера при реализации проектов промышленного освоения территорий в Арктике. Анализируются отечественный и зарубежный опыт, экономические механизмы согласования и гармонизации разновекторных и конфликтных интересов в процессе промышленного освоения территорий традиционного природопользования. Разработанные рекомендации позволят, с одной стороны, компенсировать убытки, понесенные представителями коренных малочисленных народов, а с другой - вовлечь их в процесс управления природопользованием и социально-экономического развития арктических территорий с учетом сохранения исконной среды обитания.
\end{abstract}

Ключевые слова: коренные малочисленные народы Севера, инвестиционные проекты, традиционное природопользование, экономический механизм, ущерб, Арктика.

\section{Введение}

В настоящее время в российской Арктике реализуется крупномасштабные инвестиционные проекты по развитию восьми опорных зон: Кольской, Архангельской, Ненецкой, Воркутинской, Ямало-Ненецкой, Таймыр-Туруханской, Северо-Якутской и Чукотской [1; 2]. Территории ряда субъектов Федерации, расположенных на Севере, являются важнейшими стратегическими регионами с точки зрения освоения природных ресурсов, вовлечения в хозяйственный оборот многих полезных ископаемых (углеводородов, золота, серебра, алмазов, платины, черных

() Бурцева Е. И., Потравный И. М., Гассий В. В., Слепцов А. Н., Величенко В. В., 2019 и цветных металлов, редкоземельного сырья и др.). В то же время интенсивное освоение этих территорий нередко сопровождается воздействием на исконную среду обитания коренных малочисленных народов, входит в противоречие с укладом их жизни и традиционных промыслов, затрудняет их жизнедеятельность, сопровождается отчуждением используемых коренными сообществами территорий. Данные инвестиционные проекты в значительной мере связаны с разведкой и добычей полезных ископаемых, углеводородного сырья, развитием транспортной инфраструктуры. Осуществление проектов по развитию опорных зон в российской Арктике может затронуть территории традиционного природопользования, оказать влияние на исконную среду обита- 
ния коренных малочисленных народов Севера. Недостаточный учет экологической и этнологической составляющих при обосновании и реализации инвестиционных проектов на территориях проживания и традиционной хозяйственной деятельности коренных народов может привести к возникновению конфликтных ситуаций [3].

«Концепцией устойчивого развития коренных малочисленных народов Севера, Сибири и Дальнего Востока Российской Федерации» (2009 г.) предусмотрена разработка мер по сохранению исконной среды обитания и традиционного природопользования, необходимых для обеспечения и развития традиционного образа жизни коренных малочисленных народов. Хотя федеральный закон «О гарантиях прав коренных малочисленных народов Российской Федерации» от 30 апреля 1999 г. № 82-Ф3 и установил правовые основы гарантий самобытного социально-экономического и культурного развития коренных малочисленных народов, защиты их исконной среды обитания, традиционных образа жизни, хозяйствования и промыслов. Речь идет о разработке и применении на федеральном уровне методики возмещения убытков, причиненных коренным малочисленным народам, объединениям малочисленных народов и лицам, относящимся к коренным малочисленным народам, в результате нанесения ущерба исконной среде их обитания хозяйственной деятельностью организаций всех форм собственности, а также физическими лицами. Соответствующий законопроект направлен на совершенствование порядка возмещения убытков, причиненных малочисленным народам, объединениям малочисленных народов, лицам, относящимся к малочисленным народам, в результате нанесения ущерба исконной среде их обитания хозяйственной деятельностью организаций всех форм собственности '. В этих условиях важной научной и практической задачей является разработка эффективных управленческих механизмов регулирования и гармонизации отношений бизнеса и коренных народов при промышленном освоении Арктики.

Республика Саха (Якутия) - сырьевой регион, где ведущей отраслью является горнодобывающая промышленность, деятельность которой сопровождается негативными экологическими и социальными последствиями. Коренные народы Севера могут заниматься хозяйственной деятельностью только на ненарушенных или слабо нарушенных землях. Ухудшение состояния окружающей среды, сокращение запасов возобновляемых ресурсов разрушительно воздействуют не только на традиционные виды природопользования, но и на их менталитет, культуру и традиции. С этих позиций одной из острейших проблем коренных народов становится вопрос

\footnotetext{
1 Правительство РФ обсудит возмещение ущерба коренным народам. - URL: http://ysia.ru/obshhestvo/pravitelstvo-rfobsudit-vozmeshhenie-ushherba-korennym-narodam/.
}

о справедливой компенсации вреда, наносимого территориям традиционного природопользования промышленными предприятиями, которые, в свою очередь, вызывают убытки объединениям коренных малочисленных народов. Для решения этой проблемы необходимы разработка методологии оценки убытков правообладателей земельных участков и создание экономических механизмов устойчивого развития территорий традиционного природопользования в условиях реализации инвестиционных проектов в Арктике. Однако законодательством не урегулирован порядок возмещения убытков от хозяйственной деятельности организаций в местах традиционного проживания и традиционной хозяйственной деятельности коренных малочисленных народов [4].

Сложность разработки методологии оценки и компенсации убытков коренных малочисленных народов в условиях промышленного освоения Арктики состоит также в отсутствии единства теоретических подходов и понятийного аппарата при решении данной проблемы. Например, в одних исследованиях говорится об убытках традиционной хозяйственной деятельности в зоне северного оленеводства [5], в других - об экономической оценке вреда, причиняемого арктическим экосистемам при освоении нефтегазовых и других природных ресурсов, о вреде, причиненном ресурсам традиционного природопользования [6; 7]. В научной литературе имеет место трактовка убытков землепользователей, правообладателей в российской Арктике при добыче полезных ископаемых [8]. На наш взгляд, при разработке методологии и механизмов устойчивого природопользования в Арктической зоне следует говорить о компенсации убытков, причиненных коренным малочисленным народам Севера, их объединениям, родовым общинам в условиях промышленного освоения территории, об оценке и компенсации убытков, упущенной выгоды коренным жителям при нанесении ущерба территориям традиционного природопользования в результате реализации тех или иных проектов [9; 10].

\section{Зарубежный и отечественный опыт} распределения выгод при промышленном освоении территории

Особенностью механизма распределения благ при промышленном освоении арктических территорий за рубежом является участие коренных народов в распределении прибыли добывающих компаний, в то время как в России взаимодействие бизнеса и местных сообществ происходит на основе компенсационных выплат и соглашений заинтересованных сторон о развитии данной территории. Например, в США и Канаде такой механизм распределения благ при взаимодействии бизнеса и коренных народов сводится, как правило, к проблеме распределения финансовых благ (прибыли) с участием местных сообществ. В России данный 


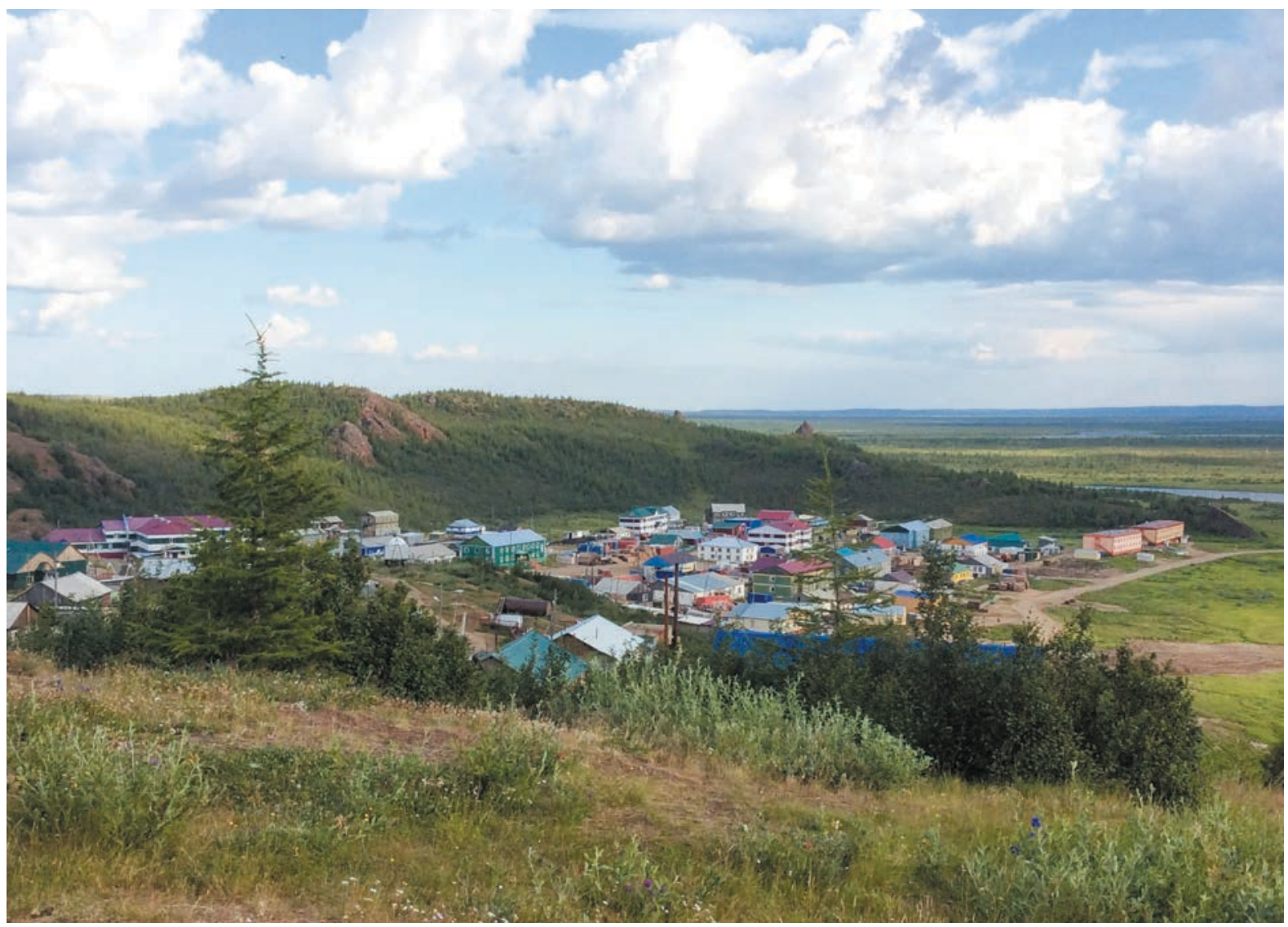

Рис. 1. Общий вид поселка Саскылах. Анабарский национальный (долгано-эвенкийский) улус (район) Республики Саха (Якутия). Август 2017 г. Фото И. М. Потравного

Fig. 1. General view of the village Saskylakh. Anabar national (dolgan-evenk) ulus (district) of the Republic of Sakha (Yakutia). August 2017. Photo by I. M. Potravny

механизм часто реализуется на основе системы компенсационных платежей, возмещения причиненного вреда в результате воздействия на территории традиционного природопользования и заключения соглашений о развитии данной территории. Такой подход реализуется на основе процедуры этнологической экспертизы проектов, которая успешно применяется, например, в Республике Саха (Якутия) с 2011 г. [11; 12].

В Канаде для указанных целей применяются различные виды соглашений между компанией и коренными народами о добыче полезных ископаемых (соглашения о воздействии и выгодах, социальноэкономические соглашения, соглашения о разведке полезных ископаемых, соглашения об участии, о сотрудничестве, меморандум о взаимодействии, письма о намерениях, договоры аренды земли (земельных участков) и др.). (реди механизмов поддержки традиционных промыслов коренных малочисленных народов Севера в России можно выделить систему закупок компанией-природопользователем продукции (рыбы, мяса дикого северного оленя, продукции собирательства и др.), выделение целевых грантов на поддержку традиционных промыслов и развития этноса.
Во взаимодействии бизнеса и коренных народов в рамках реализации инвестиционных проектов в Арктике в настоящее время превалирует принцип компенсационных выплат, который проявляется в выделении компаниями целевых инвестиций в развитие территорий. В советский период доминировал подход, при котором государство несло основное бремя ответственности и затрат на социально-экономическое развитие данной территории. С учетом зарубежного опыта можно выделить следующие типы распределения благ в рамках промышленного освоения Арктики:

- Патернализм, когда государство отвечает за распределение благ, берет на себя основные функции по развитию территории. Такой тип регулирования природопользования сложился, например, на Аляске (США).

- Социальная ответственность, когда добывающие компании играют важную роль в развитии территорий традиционного природопользования, выступают основными носителями благ и осуществляют их распределение. Примером может служить АО «Алмазы Анабара», которая занимается поиском и добычей россыпных алмазов в арктических улусах Республики Саха (Якутия) [13]. 


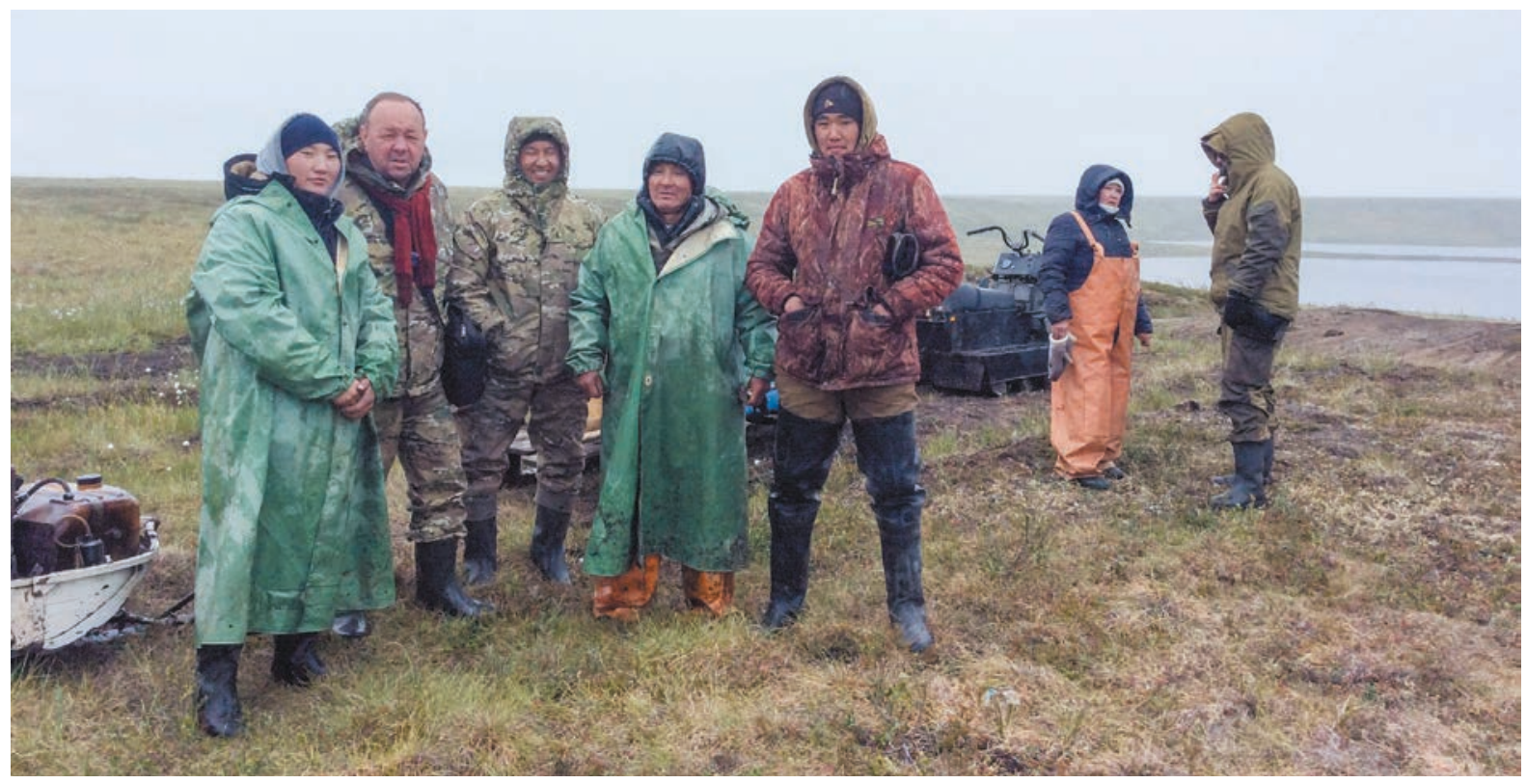

Рис. 2. Встреча с оленеводами в тундре. Поселок Хайыр. Усть-Янский улус Республики Саха (Якутия). Август 2017 г. Фото И. М. Потравного

Fig. 2. Meeting with reindeer herders in the tundra. Khayyr village, Ust-Yansky ulus (district) of the Republic of Sakha (Yakutia). August 2017. Photo by I. M. Potravny

- Партнерство. Этот тип взаимодействия сложился на Сахалине в рамках государственно-частного партнерства государства, компании и местных сообществ в распределении благ при добыче природного газа на шельфе. Сюда же относится бенефициарная система распределения благ при реализации проектов в Арктике, применяемая в Канаде.

- Распределение благ и поддержка традиционных промыслов на основе договоров. При этом в качестве основного звена распределения благ обычно выступают негосударственные организации, которые перераспределяют экономическую и нематериальную помощь индивидуально для коренных жителей, их семей, родовых общин, групп.

- Модель держателя акций, в рамках которой коренные народы получают блага как держатели акций. Такая форма взаимодействия коренных жителей и бизнеса получила развитие в США и Канаде. В России, например в арктических улусах Республики Саха (Якутия), родовые общины проявляют к этому интерес и высказывают пожелание принимать долевое участие в бизнесе добывающих компаний в качестве акционеров.

\section{Зонирование территорий традиционного природопользования}

В пределах Республики Саха (Якутия) малочисленные народы Севера проживают в 16 административных районах. Это эвены, эвенки, юкагиры, долганы, чукчи. В 1990-х годах места, где проживали коренные малочисленные народы Севера, для сохранения их исконной среды проживания были наделены статусом национальных административно-территориальных образований (рис. 1).

Традиционное природопользование зависит от природно-ресурсной основы территорий, которая, в свою очередь, обусловлена природно-климатическими условиями. Критерием выделения зон послужила природно-экологическая дифференциация территории по характеру распределения растительности - индикаторного и интегрального показателя физико-географических особенностей территорий с учетом контролирующего фактора - устойчивости природных ландшафтов к техногенным воздействиям. Например, в пределах Якутии можно выделить три зоны и семь подзон традиционного природопользования. Всего в республике проживают согласно переписи 2010 г. 36079 представителей малочисленных народов, в том числе 21008 эвенков и 15071 эвен. Поскольку природно-ресурсный потенциал на территории республики по отдельным регионам значительно различается в зависимости от географического положения и природно-климатических условий, целесообразно разрабатывать соответствующие нормативы по зонам/подзонам традиционного природопользования: в первую очередь по Северной Якутии, где планируется реализация крупных инвестиционных проектов.

\section{Традиционное природопользование коренных малочисленных народов}

Базовыми отраслями экономики многих арктических территорий являются традиционные виды природопользования - оленеводство, рыбный и охотничий промыслы, сбор дикоросов (рис. 2 и 3). Этно- 

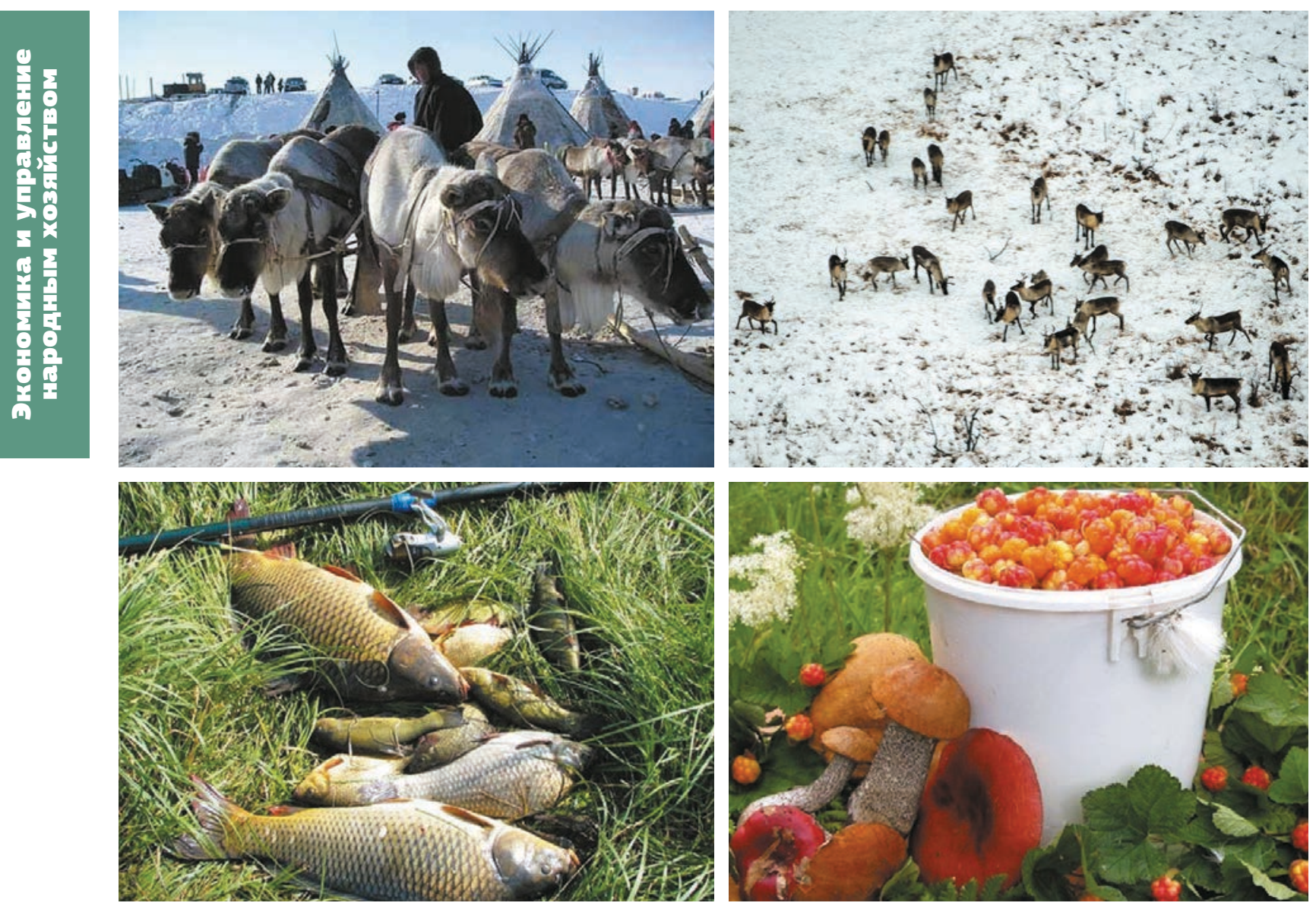

Рис. 3. Ресурсы, используемые для традиционного природопользования коренных малочисленных народов Севера Fig. 3. Resources used for traditional nature management by indigenous peoples of the North

сохраняющей отраслью традиционных видов хозяйственной деятельности коренных народов является арктическое домашнее оленеводство, с которым неразрывно связано повседневное использование родного языка, традиций и обычаев аборигенов. Домашние олени в прямом смысле кормят коренные народы: они дают главный продукт питания - мясо, а также материал для изготовления зимней одежды, обуви, для строительства передвижного жилища, используются как транспортное средство. Только в оленеводстве народы Севера не встречают конкуренции со стороны доминирующего общества.

Немаловажную роль в формировании бюджета объединений коренных народов играют охотничий промысел и добыча рыбы. Так, родовая община «Юкагир» коренных малочисленных народов Севера - юкагиров была создана охотниками-рыбаками села Юкагир Усть-Янского улуса в 2008 г. в целях защиты и сохранения традиционного образа жизни и традиционной хозяйственной деятельности коренных жителей. Площадь их охотничьих угодий для осуществления пользования животным миром составляет 1914 тыс. га. Членами общины являются 17 человек, из них 15 мужчин. Ежегодно формируются охотничье-рыбопромысловые бригады из членов общины, которые занимаются рыболовством, охотой на песца, попутным сбором бивней мамонта. Основными источниками доходов общины являются: промысловая добыча рыбы (чира, сига, ряпушки) общим объемом 52 т и добыча белого песца. При этом выручка только от реализации рыбы составила более 5 млн руб.

\section{Этнологическая экспертиза проектов}

В настоящее время на федеральном уровне разрабатывается закон об этнологической экспертизе Российской Федерации, а также обсуждается законопроект о порядке возмещения ущерба, нанесенного среде обитания коренных малочисленных народов хозяйственной деятельностью. В 2010 г. принят закон Республики Саха (Якутия) «Об этнологической экспертизе в местах традиционного проживания и традиционной хозяйственной деятельности коренных малочисленных народов Севера Республики Саха (Якутия)». Необходимость в принятии республиканского закона возникла из-за того, что не возмещался нанесенный ранее коренным народам, кочевникам при реализации проектов на территориях традиционного природопользования ущерб. Проведение такой экспертизы 


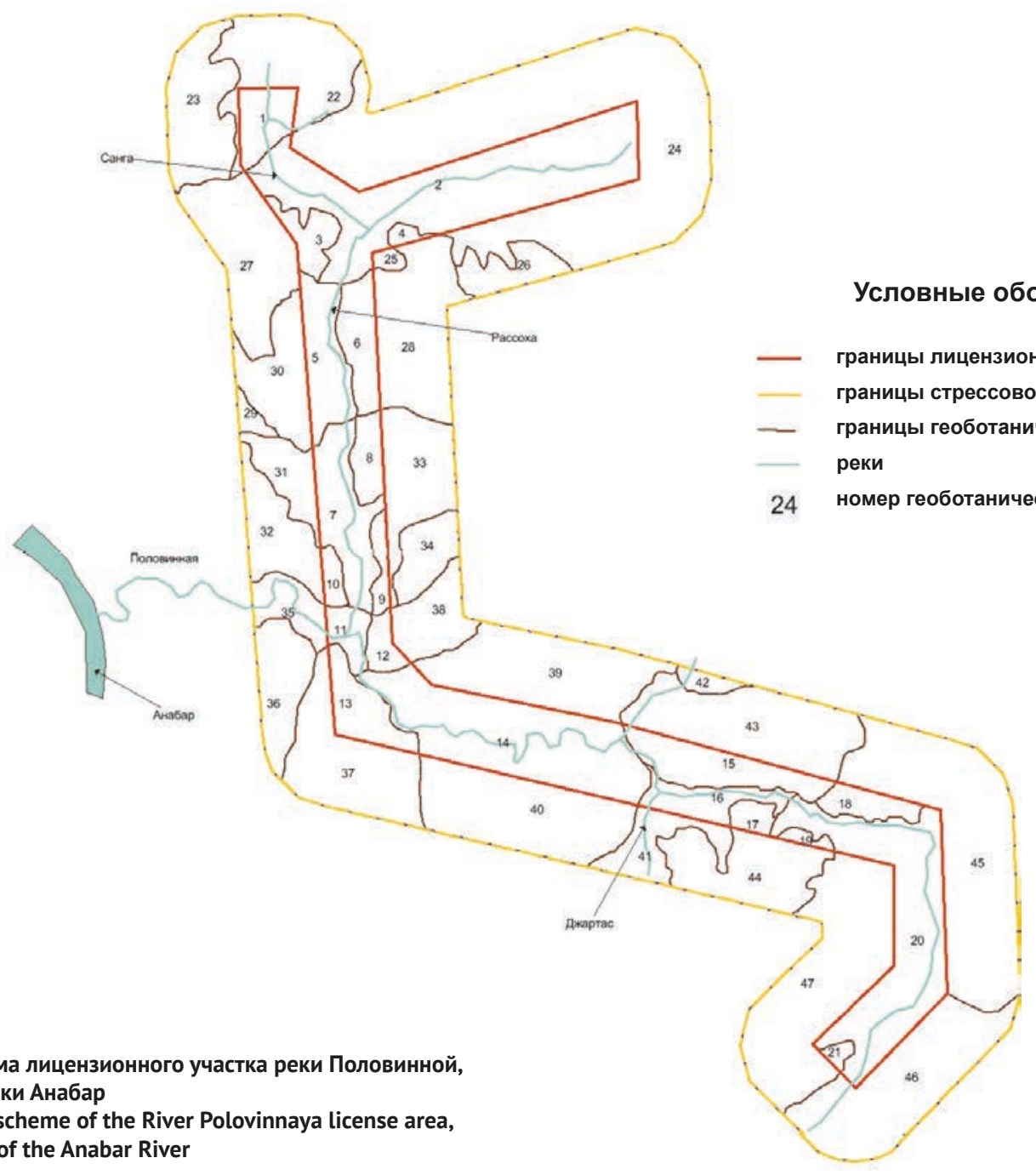

Рис. 4. Схема лицензионного участка реки Половинной, притока реки Анабар

Fig. 4. The scheme of the River Polovinnaya license area, a tributary of the Anabar River

необходимо для решения вопросов справедливой компенсации убытков и минимизации вреда территориям традиционного природопользования в результате промышленной деятельности. Таким образом, в Якутии появилась законодательная база (пока единственная в России), которая регламентирует взаимодействие недропользователей с органами власти, в том числе с национальными муниципальными образованиями и представителями родовых общин, ведущими кочевой образ жизни, а также научным сообществом при промышленном освоении территорий традиционного природопользования [14]. На сегодня государственной этнологической экспертизой Якутии рассмотрены оценка воздействия на этнологическую среду и материалы проектно-сметной документации по 13 инвестиционным бизнес-проектам. Опыт проведения данной экспертизы выявил существенные пробелы правового, социально-экономического и экологического характера при расчете компенсации убытков коренным малочисленным народам Севера, которые вызваны в основном несовершенством действующих методических подходов к их расчету.
Определение размера убытков местного населения в результате ухудшения условий ведения традиционной хозяйственной деятельности на участке

Рассмотрим пример расчета убытков при реализации проекта по геологическому изучению, включая поиск и оценку месторождений полезных ископаемых (россыпных алмазов) на реке Половинной, притоке реки Анабар в Анабарском национальном (долганоэвенкийском) улусе (районе) Республики Саха (Якутия). Заказчиком проекта выступает холдинг ООО «Арктик Капитал». Следует учитывать, что земельные угодья районов Крайнего Севера по экономической и социальной значимости относятся к территориям традиционного природопользования, где осуществляется многоотраслевая хозяйственная деятельность коренного населения, базирующаяся на многообразии местных биологических ресурсов. Осваиваемый участок находится в долине прирусловой части реки Половинной и ее притоков (рис. 4). Общая протяженность исследуемого участка составляет 75,4 км.

Убытки в зоне северного оленеводства устанавливаются по таким основным видам традиционной хо- 


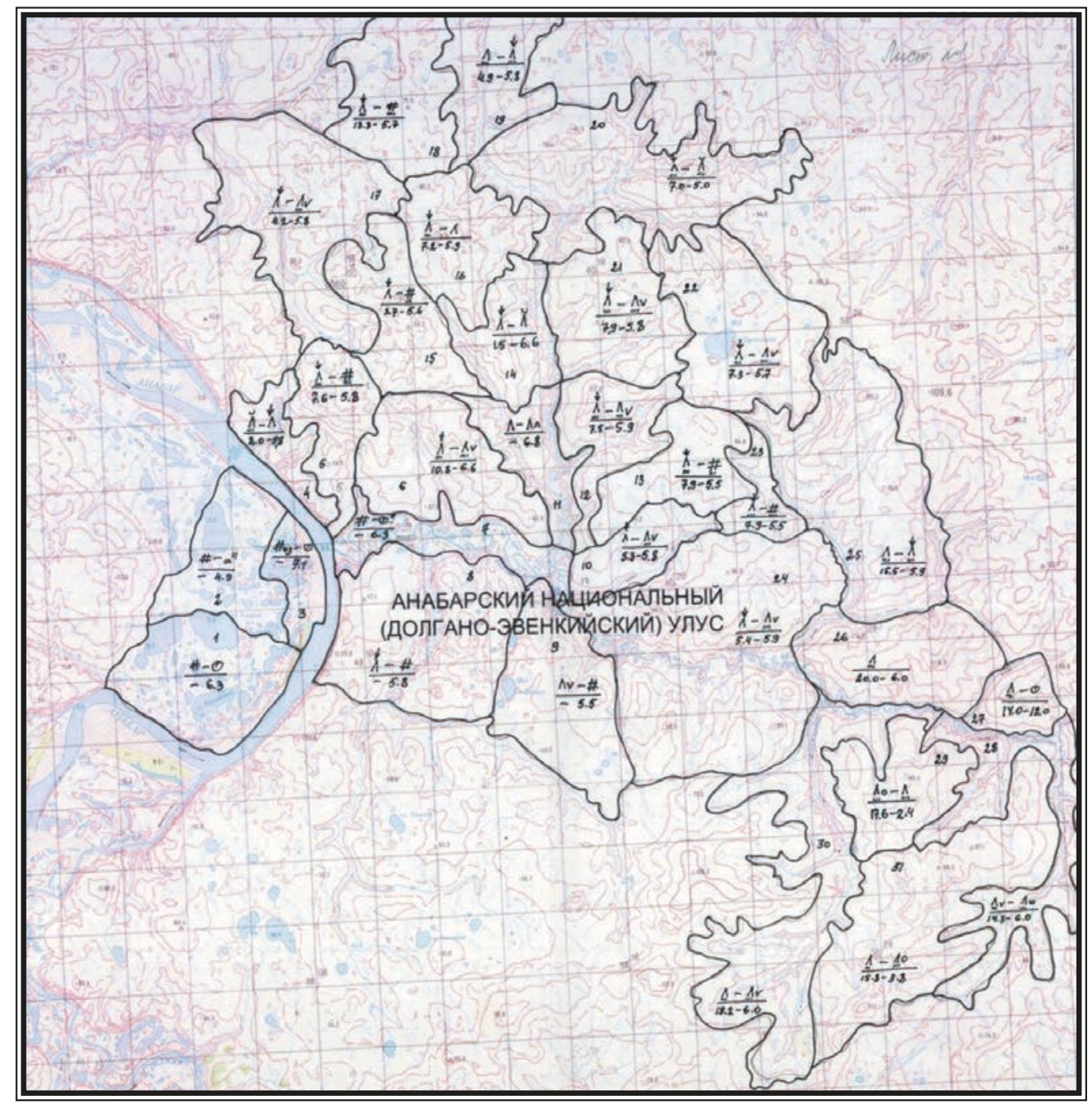

Рис. 5. Геоботаническая карта с границами лицензионного участка Fig. 5. Geobotanical map with the boundaries of the license area

зяйственной деятельности, как оленеводство, промысловая охота, рыболовство, сбор дикоросов (природных пищевых и лекарственных растений). Уменьшение продукции традиционного природопользования происходит вследствие временного изъятия земель и снижения продуктивности угодий в зоне влияния промышленных и горнодобывающих объектов. В пределах участка были выделены два типа территорий, различающихся по степени влияния на традиционное природопользование: зону отчуждения и зону стрессового воздействия. На период действия лицензии принимается, что биологические ресурсы в зоне отчуждения недоступны для традиционного природопользования, а их хозяйственные запасы подлежат компенсации.

Убытки пользователей земель традиционного природопользования в основном состоят из упущенной выгоды, величина которой определяется на основе размера годового валового дохода, получаемого пользователем данных земель с 1 га угодий. Расчетный годовой валовой доход определяется как разность стоимости валовой продукции отраслей традиционной хозяйственной деятельности и материально-технических затрат на их ведение. Убытки сельскохозяйственного производства при временном занятии земель традиционного природопользования определяются на основе стоимости хозяйственно-биологического потенциала, выражающегося их годовым хозяйственным запасом, т. е. по нормативному объему продукции, который может быть изъят без ущерба для продуктивности и стабильности экосистемы.

Расчет убытков оленеводства проводится по материалам геоботанического обследования, по результатам которого была составлена хозяйственно-геоботаническая карта масштаба 1:100 000 на бассейн реки Половинной и ее притоки (рис. 5).

На карте для каждого геоботанического контура определены значения оленеемкости. На основании хозяйственно-геоботанической карты бассейна реки был создан электронный слой хозяйственногеоботанической карты оцениваемого участка. Сни- 
жение стоимости продукции оленеводства устанавливалось по уменьшению оленеемкости пастбищ в результате их промышленного освоения. При этом принималось, что земли в пределах зоны отчуждения полностью утрачивают оленеемкость. В стрессовой зоне происходит частичное снижение оле- неемкости. Убытки определялись в расчете на год. Оленеемкость на хозяйственно-геоботанической карте показывает, какое количество оленей может выпасаться на одном гектаре на протяжении суток.

В табл. 1 показан фрагмент поконтурной ведомости хозяйственно-геоботанической карты участка

Таблица 1. Поконтурная ведомость хозяйственно-геоботанической карты участка реки Половинная

\begin{tabular}{|c|c|c|c|c|c|c|c|c|}
\hline $\begin{array}{l}\text { 돋 } \\
\text { 인 }\end{array}$ & 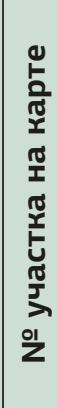 & 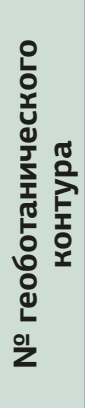 & $\begin{array}{l}\frac{\pi}{T} \\
\text { ○े } \\
m\end{array}$ & 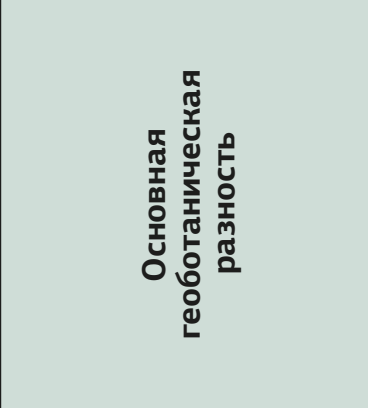 & 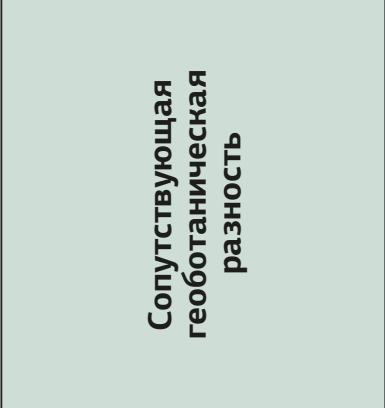 & 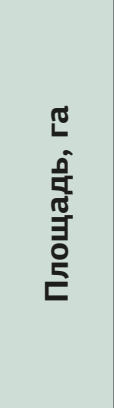 & 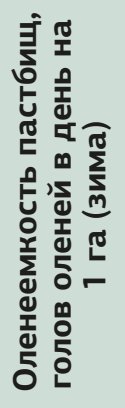 & 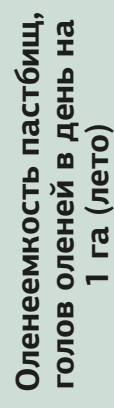 \\
\hline 1 & 1 & 19 & Отчуждение & Тундры лишайниковые & $\begin{array}{l}\text { Тундры пушицево- } \\
\text { кочкарные лишайниковые }\end{array}$ & 276,7 & 4,9 & 0,0 \\
\hline 2 & 2 & 20 & Отчуждение & $\begin{array}{l}\text { Тундры пушицево- } \\
\text { кочкарные } \\
\text { лишайниковые }\end{array}$ & $\begin{array}{l}\text { Тундры кустарничково- } \\
\text { лишайниковые }\end{array}$ & 2049,3 & 7,0 & 5,0 \\
\hline 5 & 5 & 14 & Отчуждение & $\begin{array}{l}\text { Тундры пушицево- } \\
\text { кочкарные }\end{array}$ & Тундры кустарничковые & 466,8 & 1,5 & 6,6 \\
\hline 7 & 7 & 11 & Отчуждение & Тундры моховые & Тундры мелко-бугорковые & 578,7 & 0,0 & 6,8 \\
\hline 10 & 10 & 6 & Отчуждение & Тундры ерниковые & $\begin{array}{l}\text { Болота полигонально- } \\
\text { валиковые и трещиновато } \\
\text { бугристые лишайниковые }\end{array}$ & 340,2 & 10,8 & 6,6 \\
\hline 12 & 12 & 10 & Отчуждение & $\begin{array}{l}\text { Тундры пушицево- } \\
\text { кочкарные } \\
\text { лишайниковые }\end{array}$ & $\begin{array}{l}\text { Тундры ерниково- } \\
\text { лишайниковые }\end{array}$ & 110,4 & 5,3 & 5,8 \\
\hline 18 & 18 & 27 & Отчуждение & Тундры лишайниковые & $\begin{array}{l}\text { Тундры пятнистые } \\
\text { лишайниковые }\end{array}$ & 45,6 & 14,0 & 12,0 \\
\hline 2 & 23 & 18 & Стресс & $\begin{array}{l}\text { Тундры пушицево- } \\
\text { кочкарные } \\
\text { лишайниковые }\end{array}$ & $\begin{array}{l}\text { Болота полигонально- } \\
\text { валиковые и трещиновато } \\
\text { бугристые лишайниковые }\end{array}$ & 698,4 & 3,3 & 1,4 \\
\hline 6 & 27 & 16 & Стресс & $\begin{array}{l}\text { Тундры пушицево- } \\
\text { кочкарные } \\
\text { лишайниковые }\end{array}$ & Тундра моховая & 902,1 & 1,8 & 1,5 \\
\hline 7 & 28 & 21 & Стресс & $\begin{array}{l}\text { Тундры ерниково- } \\
\text { лишайниковые }\end{array}$ & $\begin{array}{l}\text { Тундры ивняково- } \\
\text { лишайниковые }\end{array}$ & 961,2 & 3,6 & 0,8 \\
\hline 9 & 30 & 14 & Стресс & $\begin{array}{l}\text { Тундры пушицево- } \\
\text { кочкарные }\end{array}$ & Тундры кустарничковые & 538,9 & 0,4 & 1,7 \\
\hline 14 & 35 & 7 & Стресс & $\begin{array}{l}\text { Болота полигонально- } \\
\text { валиковые } \\
\text { и трещиновато бугристые }\end{array}$ & Ивняки травяные & 270,9 & 0,0 & 1,6 \\
\hline
\end{tabular}

Примечание. Оленеемкость пастбищ - показатель, характеризующий возможность природного комплекса, территории обеспечить кормом определенное поголовье оленей. Определяется в головах оленей в день на 1 га территории, т. е. оленеемкость 1 га пастбищ условно показывает, сколько оленей могут поддержать жизненные функции на 1 га пастбищ в течение суток в определенный сезон года. 
Таблица 2. Фрагмент расчета убытков оленеводства на исследуемом участке

\begin{tabular}{|c|c|c|c|c|c|c|c|c|c|}
\hline $\begin{array}{l}\text { 도 } \\
\text { ㄷ } \\
\text { 인 }\end{array}$ & 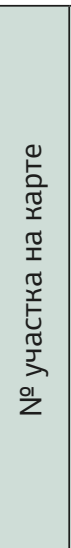 & 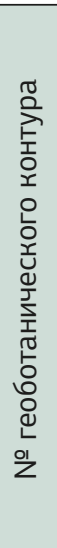 & $\begin{array}{l}\frac{\pi}{5} \\
\text { ํํํ }\end{array}$ & 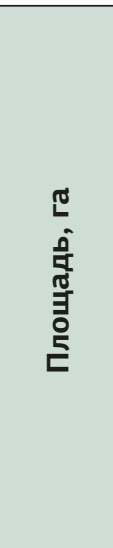 & 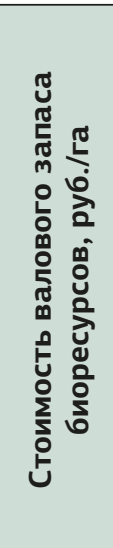 & 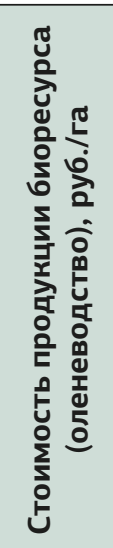 & 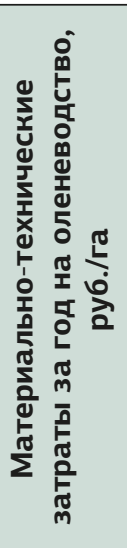 & 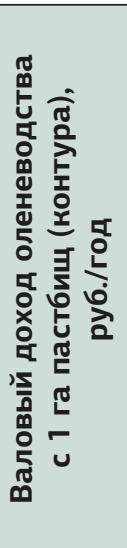 & 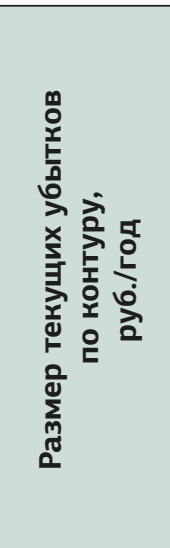 \\
\hline 1 & 1 & 19 & Отчуждение & 276,7 & 328,68 & 75,60 & 3,56 & 72,03 & 19931,48 \\
\hline 2 & 2 & 20 & Отчуждение & 2049,3 & 469,54 & 107,99 & 5,09 & 102,90 & 210881,17 \\
\hline 5 & 5 & 14 & Отчуждение & 466,8 & 442,71 & 101,82 & 4,80 & 97,02 & 45290,70 \\
\hline 7 & 7 & 11 & Отчуждение & 578,7 & 456,13 & 104,91 & 4,95 & 99,96 & 57849,10 \\
\hline 10 & 10 & 6 & Отчуждение & 340,2 & 724,44 & 166,62 & 7,85 & 158,77 & 54012,25 \\
\hline 12 & 12 & 10 & Отчуждение & 110,4 & 389,05 & 89,48 & 4,22 & 85,26 & 9413,07 \\
\hline 13 & 13 & 9 & Отчуждение & 90,1 & 368,93 & 84,85 & 4,00 & 80,85 & 7284,87 \\
\hline 18 & 18 & 27 & Отчуждение & 45,6 & 939,08 & 215,99 & 10,18 & 205,81 & 9384,85 \\
\hline 2 & 23 & 18 & Стресс & 698,4 & 223,03 & 51,30 & 2,42 & 48,88 & 34137,37 \\
\hline 6 & 27 & 16 & Стресс & 902,1 & 120,74 & 27,77 & 1,31 & 26,46 & 23870,49 \\
\hline 7 & 28 & 21 & Стресс & 961,2 & 239,80 & 55,15 & 2,60 & 52,55 & 50515,43 \\
\hline 9 & 30 & 14 & Стресс & 538,9 & 110,68 & 25,46 & 1,20 & 24,26 & 13071,53 \\
\hline 14 & 35 & 7 & Стресс & 270,9 & 105,65 & 24,30 & 1,15 & 23,15 & 6272,26 \\
\hline
\end{tabular}

реки. В табл. 2 показан фрагмент расчета убытков оленеводства на исследуемом участке.

\section{Оценка убытков охотничьего промысла}

Охота - важная традиционная сфера деятельности местного населения. Значительную часть продукции оно заготавливает для собственного потребления, что слабо отражается в официальной статистике. Оценка убытков по охотничьему промыслу основывалась на экспертных данных с использованием опросных листов и материалов по другим охотничье-промысловым районам. При оценке убытков охотничьего промысла принималось, что на рассматриваемый период земли в зоне отчуждения утрачивают значение как охотничьи угодья. В зоне стресса вследствие беспокоящего влияния продуктивность охотничьих угодий снижается на $50 \%$.

Улус относится к северным районам республики, где основным объектом охотничьего промысла является дикий северный олень. Убытки охотничьего промысла из-за изъятия земель для промышленных целей определялись на основании биологического и хозяйственного запаса промысловых животных на 1000 га охотничьих угодий, в соответствии с которым определяются квоты на добычу различного зверя. В табл. 3 представлена информация о хозяйственном запасе промысловых животных (птицы) в виде показателей их плотности.

В табл. 4 показан фрагмент расчетов по определению убытков охотничьего промысла.

\section{Оценка убытков рыболовства}

В Анабарском улусе квотируемыми видами рыб являются осетр, таймень, нельма, муксун, ряпушка, чир, сиг, пелядь, неквотируемыми - хариус, щука, язь, плотва, елец, чукучан, ерш, окунь, налим, карась, гольян, голец, тугун, ленок, валек. Река Половинная и ее притоки относятся к бассейну Анабара, но не входят в состав крупных рыбопромысловых водоемов. Регулярный рыболовный промысел здесь не ведется. Квоты на вылов рыбы 
Таблица 3. Среднегодовая продуктивность основных промысловых животных в некоторых арктических улусах (районах) Республики Саха (Якутия)

\begin{tabular}{|l|c|}
\hline $\begin{array}{c}\text { Вид промысловых } \\
\text { животных (птицы) }\end{array}$ & $\begin{array}{c}\text { Плотность населения } \\
\text { данного вида, число } \\
\text { особей на 1000 га }\end{array}$ \\
\hline Дикий северный олень & $0,214-1,680$ \\
\hline Лось & $0,353^{*}$ \\
\hline Песец белый & $0,370-0,540$ \\
\hline Горностай & $0,360-0,650$ \\
\hline Росомаха & 0,039 \\
\hline Белка & 0,360 \\
\hline Соболь & 0,902 \\
\hline Лисица & 0,142 \\
\hline Заяц, особи & $0,700-1,427$ \\
\hline Гусь & $0,300-0,700$ ** \\
\hline Куропатка, особей & 0,836 \\
\hline Глухарь & 2,910 \\
\hline Рябчик & 0,620 \\
\hline Утка & $0,525^{* *}$ \\
\hline
\end{tabular}

* Данные по плотности лося взяты по Среднеколымскому улусу.

** Число особей на 10 км русла реки, береговой линии озер. не определены. По информации ихтиологов, рыбопродуктивность реки в арктических широтах составляет в среднем 3 кг рыбы на 1 га поверхности водоема. Поскольку в уловах в основном преобладают относительно малоценные (неквотируемые) виды рыб, в расчетах принимается средняя цена 300 руб./кг. Величина субсидий составляет 30 руб. на 1 кг. Цена на рыбу с учетом субсидий составляет 330 руб. за 1 кг. Общее снижение допустимых объемов вылова будет равно произведению показателя продуктивности рыбных ресурсов в расчете на 1 га площади водной поверхности на всю площадь водной поверхности.

\section{Оценка убытков по заготовкам}

\section{съедобных дикорастущих растений}

Дикорастущие съедобные растения (дикоросы) заготавливаются местным населением в основном для собственного потребления. В условиях ограниченного сбыта стабильные цены на них не сложились. По данным опроса населения были установлены средние цены на основные виды дикоросов (бруснику, голубику, морошку, грибы). Снижение заготовок дикоросов происходит только в зоне отчуждения и не распространяется на зону стрессового воздействия. В табл. 5 приведен фрагмент расчета допустимых объемов изъятия основных видов дикоросов с единицы площади по типам геоботанических контуров, выявленных в ходе геоботанического обследования бассейна реки. Стоимость хозяйственного запаса продукции дикоросов равна произведению их хозяйственного запаса в килограммах в контуре на цену дикороса

\section{Таблица 4. Фрагмент оценки хозяйственной продуктивности дикоросов} по геоботаническим контурам

\begin{tabular}{|c|c|c|c|c|c|c|c|c|c|}
\hline \multirow{2}{*}{$\begin{array}{l}\text { 돋 } \\
\text { 인 } \\
\text { 인 }\end{array}$} & \multirow{2}{*}{ 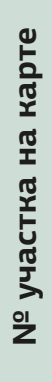 } & \multirow{2}{*}{ 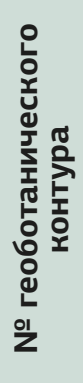 } & \multirow{2}{*}{ 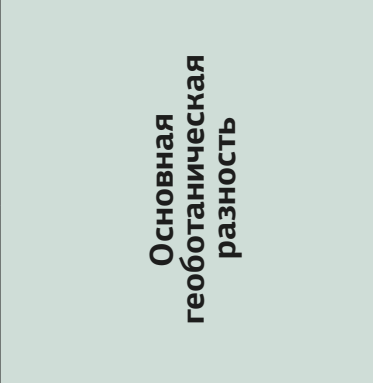 } & \multirow{2}{*}{ 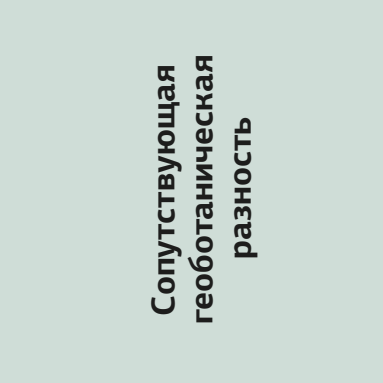 } & \multirow{2}{*}{ 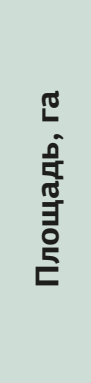 } & \multicolumn{4}{|c|}{$\begin{array}{c}\text { Хозяйственный запас } \\
\text { съедобных растений } \\
\text { по основным типам } \\
\text { геоботанических контуров, } \\
\text { кг/га }\end{array}$} \\
\hline & & & & & & 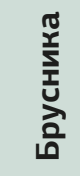 & 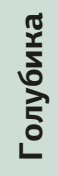 & 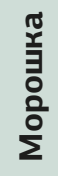 & $\begin{array}{l}\overline{\text { ڤ }} \\
\text { ํㅡㄴ }\end{array}$ \\
\hline 1 & 1 & 19 & Тундры лишайниковые & $\begin{array}{l}\text { Тундры пушицево- } \\
\text { кочкарные лишайниковые }\end{array}$ & 276,7 & 0,4 & 0,3 & 0,5 & 2,0 \\
\hline 5 & 5 & 14 & $\begin{array}{l}\text { Тундры пушицево- } \\
\text { кочкарные }\end{array}$ & Тундры кустарничковые & 466,8 & 0,6 & 0,7 & 0,9 & 2,5 \\
\hline 7 & 7 & 11 & Тундры моховые & Тундры мелко-бугорковые & 578,7 & 0,3 & 0,3 & 0,3 & 1,5 \\
\hline 10 & 10 & 6 & Тундры ерниковые & $\begin{array}{l}\text { Болота полигонально- } \\
\text { валиковые и трещиновато } \\
\text { бугристые лишайниковые }\end{array}$ & 340,2 & 0,3 & 0,3 & 0,5 & 2,0 \\
\hline 12 & 12 & 10 & $\begin{array}{l}\text { Тундры пушицево- } \\
\text { кочкарные лишайниковые }\end{array}$ & $\begin{array}{l}\text { Тундры ерниково- } \\
\text { лишайниковые }\end{array}$ & 110,4 & 0,3 & 0,3 & 0,3 & 2,0 \\
\hline
\end{tabular}




\begin{tabular}{|c|c|c|c|c|c|c|c|c|c|}
\hline \multirow{2}{*}{$\begin{array}{l}\text { 드 } \\
\text { 들 } \\
\text { 인 }\end{array}$} & \multirow{2}{*}{ 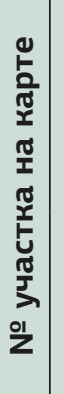 } & \multirow{2}{*}{ 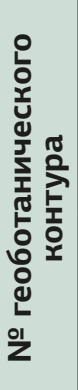 } & \multirow{2}{*}{ 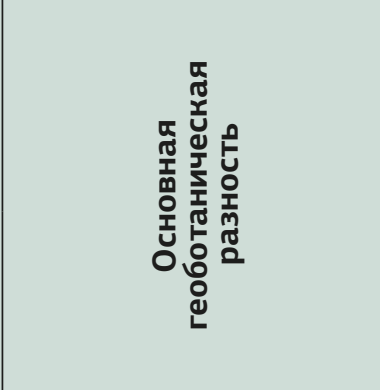 } & \multirow{2}{*}{ 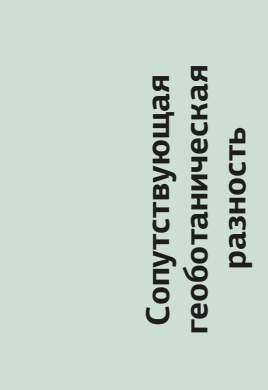 } & \multirow{2}{*}{ 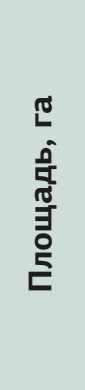 } & \multicolumn{4}{|c|}{$\begin{array}{c}\text { Хозяйственный запас } \\
\text { съедобных растений } \\
\text { по основным типам } \\
\text { геоботанических контуров, } \\
\text { кг/га }\end{array}$} \\
\hline & & & & & & 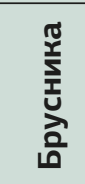 & 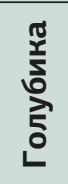 & 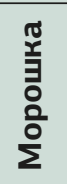 & $\begin{array}{l}\bar{\Xi} \\
\stackrel{\Xi}{0} \\
\text { 이 }\end{array}$ \\
\hline 13 & 13 & 9 & $\begin{array}{l}\text { Тундры пушицево- } \\
\text { кочкарные лишайниковые }\end{array}$ & $\begin{array}{l}\text { Тундры ерниково- } \\
\text { лишайниковые }\end{array}$ & 90,1 & 0,2 & 0,3 & 0,4 & 1,5 \\
\hline 18 & 18 & 27 & Тундры лишайниковые & $\begin{array}{l}\text { Тундры пятнистые } \\
\text { лишайниковые }\end{array}$ & 45,6 & 0,4 & 0,4 & 0,2 & 2,0 \\
\hline
\end{tabular}

Таблица 5. Фрагмент расчета стоимости хозяйственных запасов дикоросов в зоне отчуждения

\begin{tabular}{|c|c|c|c|c|c|c|c|c|c|c|}
\hline \multirow[b]{2}{*}{$\begin{array}{l}\text { 돋 } \\
\text { 인 } \\
\text { 인 }\end{array}$} & \multirow{2}{*}{$\begin{array}{l}\frac{0}{5} \\
\frac{2}{\pi} \\
\frac{2}{\pi} \\
\frac{\pi}{1} \\
\frac{\pi}{2} \\
\frac{\pi}{5} \\
\frac{\pi}{2} \\
\frac{\pi}{2}\end{array}$} & \multirow{2}{*}{ 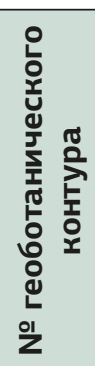 } & \multirow{2}{*}{ 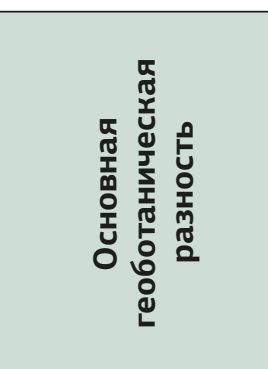 } & \multirow{2}{*}{ 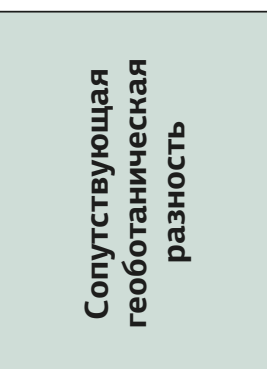 } & \multirow{2}{*}{ 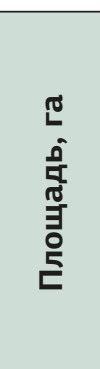 } & \multicolumn{5}{|c|}{$\begin{array}{c}\text { Стоимость потенциальной валовой } \\
\text { продукции со всей площади контура, } \\
\text { руб. }\end{array}$} \\
\hline & & & & & & 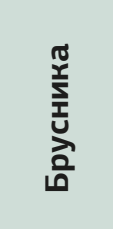 & 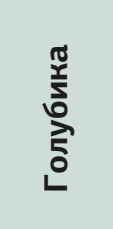 & 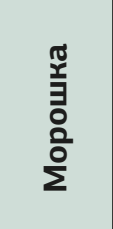 & $\begin{array}{l}\bar{\Xi} \\
\text { 른 } \\
\text { 난 }\end{array}$ & 일 \\
\hline 1 & 1 & 19 & $\begin{array}{l}\text { Тундры } \\
\text { лишайниковые }\end{array}$ & $\begin{array}{l}\text { Тундры пушицево- } \\
\text { кочкарные } \\
\text { лишайниковые }\end{array}$ & 276,7 & 13282 & 10791 & 69175 & 55340 & 148588 \\
\hline 3 & 3 & 16 & $\begin{array}{l}\text { Тундры пушицево- } \\
\text { кочкарные } \\
\text { лишайниковые }\end{array}$ & Тундры моховые & 208,2 & 4997 & 8120 & 31230 & 31230 & 75577 \\
\hline 4 & 4 & 21 & $\begin{array}{l}\text { Тундры пушицево- } \\
\text { кочкарные } \\
\text { лишайниковые }\end{array}$ & $\begin{array}{l}\text { Тундры ерниково- } \\
\text { лишайниковые }\end{array}$ & 47,2 & 1699 & 1841 & 11800 & 9440 & 24780 \\
\hline 7 & 7 & 11 & Тундры моховые & $\begin{array}{l}\text { Тундры мелко- } \\
\text { бугорковые }\end{array}$ & 578,7 & 20833 & 22569 & 86805 & 86805 & 217013 \\
\hline
\end{tabular}

в рублях за килограмм. В табл. 6 показан фрагмент определения убытков по заготовкам съедобных дикорастущих растений.

Экспертным путем было установлено, что геологическое изучение недр на данном участке может затронуть до 10\% лицензионной площади, т. е. размер возможных убытков традиционной хозяйственной площади может составить 10\% общих убытков при проведении работ.

\section{Проблема компенсации социального и экономического ущерба}

Специальная методика исчисления убытков была разработана НИИ «Гипрозем» и была утверждена Министерством регионального развития России в 2009 г.2 Она основывалась на доходном методе расчете теряемого ежегодного валового дохода правообладателей в результате нарушений земель традиционного природопользования. Однако по ней нельзя рассчитать ущерб нематериальному наследию - языку, самобытной культуре аборигенов. Остались за пределами правового регулирования

\footnotetext{
2 Методика исчисления размера убытков, причиненных объединениям коренных малочисленных народов Севера, Сибири и Дальнего Востока Российской Федерации в результате хозяйственной и иной деятельности в местах традиционного проживания и традиционной хозяйственной деятельности коренных малочисленных народов Российской Федерации. Утв. приказом Министерства регионального развития РФ от 9 декабря 2009 г. № 565.
} 
Таблица 6. Фрагмент определения убытков по заготовкам съедобных дикорастущих растений

\begin{tabular}{|c|c|c|c|c|c|c|}
\hline $\begin{array}{c}\text { № } \\
\text { п/п }\end{array}$ & $\begin{array}{c}\text { № } \\
\text { участка } \\
\text { на карте }\end{array}$ & $\begin{array}{c}\text { № геобота- } \\
\text { нического } \\
\text { контура }\end{array}$ & $\begin{array}{c}\text { Площадь, } \\
\text { га }\end{array}$ & $\begin{array}{c}\text { Потери валовой } \\
\text { продукции со всей } \\
\text { плщщади контура, } \\
\text { руб./год }\end{array}$ & $\begin{array}{c}\text { Материальные } \\
\text { затраты на сбор } \\
\text { дикоросов, } \\
\text { руб./год }\end{array}$ & $\begin{array}{c}\text { Размер } \\
\text { текущих } \\
\text { убытков, } \\
\text { руб./год }\end{array}$ \\
\hline 1 & 1 & 19 & 276,7 & 14859 & 700 & 14158 \\
\hline 2 & 2 & 20 & 2049,3 & 143451 & 6762 & 136689 \\
\hline 5 & 5 & 14 & 466,8 & 40285 & 1899 & 38386 \\
\hline 7 & 7 & 11 & 578,7 & 21701 & 1023 & 20678 \\
\hline 10 & 10 & 6 & 340,2 & 17861 & 842 & 17019 \\
\hline
\end{tabular}

вопросы расчета убытков при условии предоставления новых земельных участков взамен изымаемых, вопросы статуса оказавшихся под косвенным влиянием промышленного освоения территорий. Поэтому нужен федеральный закон об этнологической экспертизе, чтобы распространить опыт Якутии на другие регионы.

Существующие подходы к оценке убытков, причиненных землепользователям, не учитывают социальные аспекты влияния проектов. На наш взгляд, компании, занимающиеся производственной деятельностью на территориях традиционного природопользования, должны компенсировать и социальный ущерб в целях повышения качества жизни коренного населения в виде социальных мероприятий (строительства социальных объектов, финансирования этнокультурных мероприятий, трудоустройства) [15]. Практика расчета убытков коренным народам при проведении оценки воздействия на этнологическую среду по данной методике показывает возможность получения ре- зультатов, которые могут существенно отличаться у разных заказчиков (табл. 7).

Согласно данной методике возможные убытки родовых общин должны быть рассчитаны с использованием коэффициента пересчета теряемого ежегодного валового дохода в упущенную выгоду, который выражает срок восстановления нарушенного производства. Однако традиционное производство не может быть восстановлено, если не восстановлены нарушенные природные ресурсы. В существующей методике не отражены вопросы, связанные с получателями компенсации (общинами, органами местного самоуправления, общественными организациями), требуют корректировки вопросы определения зон стрессового воздействия проекта по мере удаления от промышленного объекта.

\section{Выводы и рекомендации}

Для расчета убытков целесообразно применять доходный подход по показателю упущенной выгоды. Упущенная выгода землепользователей зависит

Таблица 7. Размер убытков родовой коренной общины «Бугат» от стрессового воздействия ГМК «Тимир» по материалам разных заказчиков, руб.

\begin{tabular}{|c|c|c|c|c|}
\hline \multirow{2}{*}{$\begin{array}{c}\text { Вид } \\
\text { традиционной } \\
\text { хозяйственной } \\
\text { деятельности }\end{array}$} & \multicolumn{2}{|c|}{$\begin{array}{c}\text { Институт «Якутнипроалмаз» } \\
\text { АК «АЛРОСА» }\end{array}$} & \multicolumn{2}{|c|}{ ЗАО ГМК «Тимир» } \\
\hline & $\begin{array}{l}\text { Ежегодный } \\
\text { теряемый } \\
\text { доход } \\
\text { (2012 г.) }\end{array}$ & $\begin{array}{c}\text { Упущенная выгода до } \\
\text { ввода в эксплуатацию } \\
\text { Таежного ГОКа } \\
\text { (2012-2026 гг.) }\end{array}$ & $\begin{array}{l}\text { Ежегодный } \\
\text { теряемый } \\
\text { доход } \\
\text { (2014 г.) }\end{array}$ & $\begin{array}{c}\text { Упущенная выгода до } \\
\text { выхода предприятия на } \\
\text { проектную мощность } \\
\text { (2015-2019 гг.) }\end{array}$ \\
\hline Оленеводство & 956682,3 & 13661424 & 2736,84 & 16588 \\
\hline Охотпромысел & 25279,9 & 360997 & 508,86 & 3084,18 \\
\hline Собирательство & 447513,2 & 6390489 & 1950,66 & 11822,9 \\
\hline Рыболовство & 170605,0 & 2436240 & 5196,36 & 31495,1 \\
\hline Всего & 1600080,5 & 22849149,8 & 10392,7 & 64660 \\
\hline
\end{tabular}


прежде всего от площади техногенных нарушений, которая, в свою очередь, определяется по радиусу воздействия промышленных объектов. Для оценки интенсивности воздействия промышленных объектов на природные комплексы предлагается учитывать такие факторы, как класс опасности проекта, характер нарушений (площадные - карьеры, другие промышленные объекты, линейные - трубопроводы, автомобильные дороги и пр.).

На наш взгляд, методы оценки потерь территорий традиционного природопользования и проживающего на них коренного населения, основанные на учете показателей снижения дохода от традиционной деятельности, должны быть дополнены рядом экологических и социально-экономических издержек, которые несет дополнительно компаниянедропользователь в связи с изменением условий жизнедеятельности населения (создание рабочих мест, расходы на образование, изменение образа жизни и т. п.).

Одной из основных особенностей проектов по хозяйственному освоению территорий традиционного природопользования является многокритериальность, обусловленная существованием разноплановых критериев у разных социально-экономических групп, органов местного самоуправления и коренного населения. При этом коммерческая эффективность, к которой обычно пытаются свести результаты проекта, не всегда может быть использована при оценке преимуществ различных проектных альтернатив. В проектах, результатами реализации которых могут быть последствия, затрагивающие социальные, экологические, этнологические, культурные и другие аспекты общественной жизни, большую важность приобретают критерии, отражающие степень достижения соответствующих целевых установок. В условиях многокритериальности стратегий хозяйственного освоения территорий традиционного природопользования, различий в значимости отдельных критериев для каждой из сторон, интересы которых в той или иной степени затрагиваются этой сферой деятельности, обоснования рационального варианта развития таких территорий значительно осложняются. Очевидным принципом при оценке стратегий хозяйственного освоения территорий традиционного природопользования является их выгодность и согласованность интересов основных сторон. При этом выгодность в данном случае нельзя однозначно определять только по соотношению экономических результатов и затрат, связанных с их реализацией. Это понятие должно включать в себя и степень удовлетворения интересов различных сторон, зависящую от последствий реализации таких стратегий. В свою очередь, согласованность интересов может быть обеспечена только в том случае, если последствия реализации стратегий являются «Выгодными» для всех сторон, цели и интересы которых могут не совпадать.

Для смягчения негативных социальных последствий проведения промышленных работ в местах традиционного проживания и хозяйственной деятельности коренных малочисленных народов необходимо заключать трехстороннее соглашение о сотрудничестве и финансировании конкретных программ содействия устойчивому развитию между заказчиком проекта, органами власти и представителями коренных малочисленных народов Севера. При разработке на федеральном уровне законопроектов «Об этнологической экспертизе Российской Федерации» и «О порядке возмещения ущерба, нанесенного среде обитания коренных малочисленных народов хозяйственной деятельностью» необходимо учесть опыт проведения этнологической экспертизы проектов в Республике Саха (Якутия). Тем самым будет сформирована модель взаимодействия всех задействованных сторон, в том числе местных сообществ при промышленном освоении Арктики ${ }^{3}$.

Статья подготовлена при финансовой поддержке гранта Российского фонда фундаментальных исследований, проект «Разработка методологии оценки ущерба коренным малочисленным народам Севера при промышленном освоении территорий традиционного природопользования» № 17-02-00214.

\section{Литература}

1. Потравный И. М., Моторина М. А. Развитие опорных зон в Российской Арктике на основе проектного подхода // Горизонты экономики. - 2017. - № 6 (39). - C. 31-37.

2. Novoselov A., Potravny I., Novoselova I., Gassiy V. Selection of priority investment projects for the development of the Russian Arctic // Polar Science. - 2017. Vol. 14, Dec. - P. 68-77.

3. Novoselov A., Potrannii I., Novoselova I., Gassiy V. Conflicts Management in Natural Resources Use and Environment Protection on the Regional Level // J. of Environmental Management and Tourism: ASERS Publ. - 2016. - Vol. 7, № 3 (15). - P. 407-415.

4. Слепцов А. Н. Вопросы нормативного закрепления этнологической экспертизы в местах традиционного проживания и хозяйственной деятельности коренных малочисленных народов Севера на примере Якутии // Юрист. - 2017. — № 19. - С. 42-46. 5. Гладков А. А., Носов С. И., Сапожников П. М. Принципы определения убытков традиционной хозяйственной деятельности в зоне северного оленеводства // Современные проблемы управления проектами в инвестиционно-строительной сфере и при-

\footnotetext{
3 Ученые РФ создали инструмент оценки инвестпроектов в Арктике для этнологической экспертизы. - URL: http://tass. ru/v-strane/5086728.
} 
родопользовании: Материалы VIII международной научно-практической конференции. - М.: РЭУ им. Г. В. Плеханова, 2018. - С. 95-101.

6. Игнатьева М. Н., Логинов В. Г., Литвинова А. А. и др. Экономическая оценка вреда, причиняемого арктическим экосистемам при освоении нефтегазовых ресурсов // Экономика региона. - 2014. - № 1 (37). - C. 102-111. — DOI: 10.17059/2014-1-9.

7. Логинов В. Г., Игнатьева М. Н., Балашенко В. В. Вред, причиненный ресурсам традиционного природопользования, и его экономическая оценка // Экономика региона. - 2017. - Т. 13, № 2. - С. 396409. - DOI: 10.17059/2017-2-6.

8. Носов С. И., Бондарев Б. Е. Определение убытков землепользователей в Российской Арктике при добыче полезных ископаемых // Коренные народы Сибири: история, традиции и современность: Материалы региональной научно-практической конференции / Сост. О. П. Доможакова. - Абакан: Хакас. кн. изд-во, 2018. - С. 144-151.

9. Бурцева Е. И. Компенсация убытков, причиненных объединениям коренных малочисленных народов в условиях промышленного освоения территорий // Экономика природопользования. - 2018. - № 2. С. 23-38.

10. Самсонова И. В., Павлова М. Б. Российский и международный опыт возмещения ущерба коренным малочисленным народам при ресурсном освоении территорий // Арктика. XXI век. Гуманитар. науки. 2017. — № 3 (13). - С. 52-61.

11. Слепцов А. Н. Этнологическая экспертиза в местах традиционного проживания и традиционной хозяйственной деятельности народов Севера: региональный опыт правового регулирования и правоприменительной практики // Евраз. юрид. журн. 2013. — № 12 (67). - С. 71-75.

12. Потравный И. М., Гассий В. В., Тамбовцева Т. Т. Этнологическая экспертиза как инструмент согласования интересов целевых групп в сфере традиционного природопользования // Экономика природопользования. - 2016. - № 3. - С. 80-92. 13. Потравный И. М., Гассий В. В., Черноградский В. Н., Постников А. В. Социальная ответственность компаний-недропользователей на территории традиционного природопользования как основа партнерства власти, бизнеса и коренных малочисленных народов // Арктика: экология и экономика. - 2016. — № 2 (22). - C. 56-63.

14. Слепцов А. Н. Государственная этнологическая экспертиза Республики Саха (Якутия) // Арктика XXI век. Гуманитар. науки. - 2015. - № 1 (4). - C. 15-24.

15. Бурцева Е. И., Кычкин В. Р., Федоров С. П. и др. Проблема компенсации экологического и социального ущерба в Якутии, вызванного добычей алмазов // Регион. экономика: теория и практика. - 2009. № 40 (133). - C. 8-17.

\section{Информация об авторах}

Бурцева Евдокия Иннокентиевна, доктор географических наук, профессор кафедры «Экономика и управление территориями», Северо-Восточный федеральный университет им. М. К. Аммосова (677000, Россия, Республика Саха (Якутия), Якутск, ул. Белинского, 58), e-mail: burtseva1999@mail.ru.

Потравный Иван Михайлович, доктор экономически наук, профессор кафедры «Управление проектами и программами», Российский экономический университет им. Г. В. Плеханова (117997, Россия, Москва, Стремянный пер., 36), e-mail: ecoaudit@bk.ru.

Гассий Виолетта Валерьевна, доктор экономических наук, профессор кафедры «Государственное и муниципальное управление», Кубанский государственный университет (350040, Россия, Краснодар, Ставропольская ул., 149), e-mail: vgassiy@mail.ru.

Слепцов Анатолий Николаевич, кандидат юридических наук, заведующий кафедрой «Арктическое право и право стран Азиатско-Тихоокеанского региона», Северо-Восточный федеральный университет им. М. К. Аммосова (677000, Россия, Республика Саха (Якутия), Якутск, ул. Белинского, 58), e-mail: uyandi@ mail.ru.

Величенко Валерий Владимирович, кандидат биологических наук, ведущий научный сотрудник, ученый секретарь НИИ прикладной экологии Севера, Северо-Восточный федеральный университет им. М. К. Аммосова (677000, Россия, Республика Саха (Якутия), Якутск, ул. Белинского, 58), e-mail: ipes-08@mail.ru.

\section{Библиографическое описание әанной сmambu}

Бурцева Е. И., Потравный И. М., Гассий В. В. и др. Вопросы оценки и компенсации убытков коренным малочисленным народам в условиях промышленного освоения Арктики // Арктика: экология и экономика. 2019. — № 1 (33). — C. 34-49. — DOI: 10.25283/2223-4594-2019-1-34-49. 